\title{
Epidemiological Analysis of Penile Neoplasms in Brazil and Its Social Determinants
}

\author{
Marcelo Cabral Lamy de Miranda ${ }^{1}$, Janine Pereira da Silva ${ }^{1}$, Arthur Brunelli Sales ${ }^{1}$, Eliney Ferreira Faria ${ }^{2}$, Maria \\ Carlota de Rezende Coelho ${ }^{1}$, Lúcia Helena Sagrillo Pimassoni ${ }^{1}$, Valmin Ramos-Silva ${ }^{1}$ \\ ${ }^{1}$ Escola Superior de Ciências da Santa Casa de Misericórdia de Vitória (EMESCAM),Vitória, ES, Brazil \\ ${ }^{2}$ Department of Urology, Hospital de Amor (HA) - Barretos, SP, Brazil \\ Correspondence: Valmin Ramos-Silva - Escola Superior de Ciências da Santa Casa de Misericórdia de Vitória - Avenida \\ Nossa Senhora da Penha, 2190 - Santa Luíza - CEP: 29045-402 - Vitória (ES), Brazil.
}

Received: October 26, 2020

doi:10.11114/ijsss.v9i1.5059
Accepted: November 20, $2020 \quad$ Available online: November 24, 2020

URL: https://doi.org/10.11114/ijsss.v9i1.5059

\section{Abstract}

Introduction: Penile neoplasms, although preventable, are frequent even among young persons. Penile neoplasms have a high risk of not only morbidity and mortality but also important psychosocial repercussions.

Objective: To describe the epidemiology of penile neoplasms in Brazil.

Method: This was an epidemiological, descriptive and cross-sectional study. Data on all the notified cases of penile neoplasms in Brazil between 1985 and 2015 were obtained from RCPBP/INCA and DATASUS databases.

Results: Of 9625 notified cases of penile neoplasms, a higher proportion of cancer patients was observed among patients aged between 40 and 70 years (63.5\%) and among smokers (21\%), in Brown and Caucasian patients (80\%), those who were married (54.2\%), had high alcohol intake levels (16\%) and with lower levels of education: illiterate people $(21.5 \%)$, those with incomplete elementary school education $(36.6 \%)$ and those with complete elementary school education $(10.3 \%)$. The lesions were located in the glans $(22.6 \%)$, prepuce $(7.5 \%)$ and the penile body $(7.5 \%)$. Higher mortality rates were observed in the age-group 50 to 80 years and in among patients from the Northeast (31.4\%) and Southeast (39.2\%) regions of the country.

Conclusion: Penile neoplasms, which mainly affect young people that are economically active, are prevalent in Brazil and the majority of patients present with an advanced stage of the disease. They are Brown and Caucasian, married, with poor education and live in the Northeast and Southeast regions of the country.

Keywords: Penile Neoplasms, Epidemiology, mortality, social determinants of health

\section{Introduction}

Diseases affecting the male sex organs present a public health problem of concern. For instance, penile neoplasms have a substantial impact in daily life of those who suffer from this condition. This is because they influence the entire family dynamics and are a major source of social challenges for patients, their families and the health system. The Política Nacional de Ação Integral à Saúde do Homem - PNAISH (National Politics for Integral Men's Health Assistance) was created to address this health challenges in vulnerable population by effectively involving men in primary care and providing the necessary environment to facilitate the reduction in morbidity and mortality associated with this type of cancer. The PNAISH policy also addressed actions focusing on adolescence that are related to preventing violence, smoking, alcohol and the use of other drugs of abuse as well as actions that focused on sexual and reproductive rights (Secretaria de Atenção à Saúde, 2008).

Published evidences states that this health vulnerability among men could be attributed to sociocultural and social barriers that affect the health of individuals and populations, setting the stage for inequalities and disparities in health (Andrade et al., 2014).

Severe disease among men may affect the whole family especially where men still have a cultural role of providing family income. Additionally, a mismatched schedules between work engagements and medical care services in public health care units and the huge demand for health services that leads to long queues in health facilities and an unfriendly 
hospital environment deter men from accessing health services (Ellemers, 2018; Maroto-Navarro, Ocaña-Riola, Gil-Garcia, \& Garcia-Calvente, 2019; Freitas \& Coelho, 2019).

The concept of masculinity is currently changing with new cultural processes and this permits men to take a new perspective of their own health. This is now changing the existing paradigm that regards men as individuals who neglect their own health (Rice, Kim, Liu, Fall, \& Galligan, 2017; Ferraz \& Kraiczyk, 2010).

Although penile neoplasms are more prevalent among patients aged fifty years and older, this disease may also affect younger people. The etiological factors associated with a cancer at an earlier age include poverty, lower levels of education, poor hygiene, the persistence of the prepuce and infection with Human Papiloma Virus (HPV). Penile neoplasms which contribute to $2.0 \%$ of all types of cancers affecting the male population in Brazil, are more frequent in the North and Northeast regions of the country (Instituto Nacional do Câncer [INCA], 2014).

A study conducted between 2009 and 2016, reviewed mortality records of 5603 cases of penile neoplasms in Brazil. The study showed a higher mortality among the Caucasian (46.1\%) and the Brown (37.9\%), among those aged 35 to 49 years (18.5\%) and 60 to 79 years (39.1\%), among those in the following states in Acre, Maranhão and Tocantins and in the following regions: the North region (with a higher variation), followed by the Northeast and Southeast regions (with a lower variation) of the country (Lisbôa, 2019).

This study intends to fill some structural gaps in men's health and provide evidences that there are still challenges despite actions focused on promoting men's health and penile neoplasms being preventable. These challenges are mainly due to cultural aspects, social inequalities and iniquities. Thus, the objective of this study is to describe the epidemiology of and characterize patients with penile neoplasms in Brazil based on the social determinants of health.

\section{Methods}

This was an epidemiological, descriptive and cross-sectional study of data on the incidence of penile neoplasms in Brazil between 1985 and 2015 available in the Registro de Câncer de Base Populacional - RCBP (National Basis Cancer Registration) and at the Instituto Nacional do Câncer - INCA (National Cancer Institute) databases. To describe mortality rates, data between 1996 and 2015 was obtained from a public national mortality database referred to as Sistema de Informação sobre Mortalidade - SIM (Information system of mortality) belonging to the national health system of Brazil (Sistema Único de Saúde - SUS) that is available at the department of data processing of the national health system's (Departamento de Informática do Sistema Único de Saúde - DATASUS) website.

The data from RCBP, a recommended source of information, is comprised of all new cases of all types of cancer collated through an active search on several different sources of notified information from institutions that provide both public and private services to these patients, including the SIM system. The RCBP database has information on the temporality of neoplasms, ultimate interventions measures, treatment evaluation, identification of risk factors and survival rates and the insight from epidemiological studies (Peres et al., 2016).

We conducted a searched on INCA's website on the $3^{\text {rd }}$ and $4^{\text {th }}$ of April 2017 using the following variables: number of notified cases of penile neoplasms in Brazil in each year from 1985 to 2015, and patient information including age group, level of education, marital status, ethnicity, alcohol consumption level, smoking status, federal unit of the patient and the precise localization of the lesion.

We collected the data from the SIM system using the $10^{\text {th }}$ International Classification of Diseases (ICD-10) C60 code that represents for Malignant Neoplasms of Penis. Using this code, the following patient variables were obtained: age, ethnicity, level of education, marital status and whether the patient was alive or dead.

We used SPSS software (Chicago, EUA, version 25, series 10101141221) to analyze the data. We used descriptive statistics to summarize the data and displayed the data using contingency tables with absolute and relative frequencies. Patients/cases with missing information were excluded from the analysis.

This study used only secondary data that was publicly available and was therefore qualified for an exempted from ethical oversight, in accordance with Resolution 510/2016, of the National Health Council (Conselho Nacional de Saúde [CNS], 2016).

\section{Results}

\subsection{Demographic Characteristics}

From 1985 to 2015, 9625 cases of penile neoplasms were documented in the RCBP/INCA systems.

There was a lower proportion of cases among black and native individuals, those with a lower level of education and among those who were married. A higher frequency of penile neoplasms was observed in those over 40 years of age, although cases in childhood and adolescence have been notified. Due to missing data concerning smoking and alcohol consumption, this information was not summarized. Table 1 summarizes this information. 
Table 1. Demographic characteristics of patients with penile neoplasms based on the notified cases in RCBP/INCA in Brazil from 1985 to 2015. $(\mathrm{N}=9625)^{1}$

\begin{tabular}{|c|c|c|}
\hline Variable of interest & Number & Frequency $(\%)$ \\
\hline \multicolumn{3}{|l|}{ Ethnicity (n = 5 584) } \\
\hline - Brown & 3640 & 48.6 \\
\hline - Caucasian & 2352 & 31.4 \\
\hline - Black & 459 & 6.1 \\
\hline - Yellow & 100 & 1.3 \\
\hline - Natives & 26 & 0.3 \\
\hline - Non-specified & 918 & 12.3 \\
\hline \multicolumn{3}{|l|}{ Level of education ( $n=5584)$} \\
\hline - Illiterate & 1609 & 21.5 \\
\hline - Incomplete elementary school & 2744 & 36.6 \\
\hline - Complete elementary school & 769 & 10.3 \\
\hline - High School & 386 & 5.1 \\
\hline - Incomplete higher education & 14 & 0.2 \\
\hline - Complete higher education & 62 & 0.8 \\
\hline - Non-specified & 1911 & 25.5 \\
\hline \multicolumn{3}{|l|}{ Marital status $(n=6673)$} \\
\hline - Married & 4063 & 54.2 \\
\hline - Divorced & 310 & 4.2 \\
\hline - Single & 1711 & 22.9 \\
\hline - Common-law marriage & 77 & 1.0 \\
\hline - Widow & 512 & 6.8 \\
\hline - Non-specified & 822 & 10.9 \\
\hline \multicolumn{3}{|l|}{ Alcohol consumption $(n=3$ 587) } \\
\hline - Yes & 1217 & 16.2 \\
\hline - No & 2029 & 27.1 \\
\hline - Consumption in the past & 341 & 4.6 \\
\hline - Non-specified & 3570 & 47.6 \\
\hline - Does not applies or not evaluated & 338 & 4.5 \\
\hline \multicolumn{3}{|l|}{ Smoking $(n=3$ 550) } \\
\hline - Yes & 1614 & 21.6 \\
\hline - No & 1936 & 25.8 \\
\hline - Consumption in the past & 416 & 5.5 \\
\hline - Non-specified & 3232 & 43.1 \\
\hline - Does not applies or not evaluated & 297 & 4.0 \\
\hline
\end{tabular}

${ }^{1}$ The total number of cases $(9$ 625) includes all variables that lacks information, and these were excluded from the analysis. The respective number of cases was indicated in each case.

Table 2. Frequency of penile neoplasms according to age group from 1985 to 2015, notified in RCBC/INCA, Brazil $(\mathrm{n}=7$ 495)

\begin{tabular}{lc}
\hline Age group (years) & Number of cases/Frequency $(\%)$ \\
\hline$<19$ & $18 / 0.2$ \\
$20-29$ & $156 / 2.1$ \\
$30-39$ & $614 / 8.2 /$ \\
$40-49$ & $1281 / 17.1$ \\
$50-59$ & $1740 / 23.2$ \\
$60-69$ & $1735 / 23.1$ \\
$70-79$ & $1265 / 16.9$ \\
$>80$ & $685 / 9.1$ \\
Non-informed & $1 / 0.0$ \\
\hline
\end{tabular}

\subsection{Tumor Characteristics}

The lesions were in the prepuce $(726 / 7.8 \%)$, glans $(2248 / 24.3 \%)$, body of penis $(744 / 8.0 \%)$, superimposed lesions $(322 / 3.5 \%)$ and non-specified (5 225/56.4\%). The majority of tumors were at an advanced stage. The Table 3 displays data concerning the T classification for tumor staging of the notified cases in RCBP/INCA systems from 1985 to 2015, where a high tissue invasion is observed. 
Table 3. Tumor T classification and tumor staging notified in RCBP/INCA, from 1985 to 2015 (n=3 150)

\begin{tabular}{lcc}
\hline Tumor (T) classification/staging & Number & Frequency $(\%)$ \\
\hline T0 - No evidence of primary tumor & 88 & 2.8 \\
T1 - Tumor invades the subepithelial connective tissue & 675 & 21.4 \\
T2 - Tumor invades the spongy or cavernous body of penis & 865 & 27.4 \\
T3 - Tumor invades the urethra & 821 & 26.0 \\
T4 - Tumor invades other adjacent structures & 706 & 22.4 \\
\hline
\end{tabular}

\section{Mortality from penile neoplasms}

The Table 4 shows the number of deaths among patients with penile cancer according to their age-groups ( $\mathrm{n}=3$ 678) and according to their region of residence within the country $(n=5620)$, stratified by ethnicity. It was observed that $45.6 \%$ of deaths were among non-Caucasian patients and in those from the North region. The Midwest region had the lowest number of deaths.

Table 4. Number of deaths among patients with penile cancer, notified in SIM/DATASUS, from 1996 to 2015 , Brazil

\begin{tabular}{|c|c|c|c|c|c|c|c|}
\hline & \multicolumn{6}{|c|}{ Ethnicity } & \multirow{2}{*}{$\begin{array}{c}\text { TOTAL } \\
\text { (Number/freq. } \\
(\%))\end{array}$} \\
\hline & Caucasian & Black & Yellow & Brown & Native & Non-specified & \\
\hline \multicolumn{8}{|l|}{$\begin{array}{c}\text { Age group } \\
\text { (year) }\end{array}$} \\
\hline-00 a 19 & 2 & - & - & 2 & - & 2 & $6 / 0.2$ \\
\hline-20 a 29 & 26 & 5 & - & 45 & 1 & 13 & $90 / 2.4$ \\
\hline-30 a 39 & 134 & 35 & 1 & 189 & 2 & 57 & $418 / 11.4$ \\
\hline-40 a 49 & 323 & 58 & 6 & 335 & 5 & 129 & $856 / 23.3$ \\
\hline-50 a 59 & 472 & 72 & 2 & 444 & 4 & 137 & $1131 / 30.8$ \\
\hline-60 a 69 & 573 & 80 & 7 & 379 & 5 & 133 & 1 177/32.0 \\
\hline $\begin{array}{c}\text { TOTAL } \\
\text { (Number/freq. } \\
(\%))\end{array}$ & $1530 / 41.6$ & $250 / 6.8$ & $16 / 0.4$ & $1394 / 37.9$ & $17 / 0.5$ & $471 / 12.8$ & $3678 / 100.0$ \\
\hline \multicolumn{8}{|l|}{$\begin{array}{c}\text { Regions of } \\
\text { Brazil }\end{array}$} \\
\hline - North & 61 & 13 & 1 & 299 & 11 & 42 & $427 / 7.6$ \\
\hline - Northeast & 399 & 147 & 12 & 955 & 5 & 247 & $1765 / 31.4$ \\
\hline - Southeast & 1219 & 161 & 16 & 518 & 2 & 291 & 2 207/39.3 \\
\hline - South & 622 & 14 & - & 51 & - & 75 & $762 / 13.5$ \\
\hline - Midwest & 166 & 43 & 1 & 179 & 8 & 62 & $459 / 8.2$ \\
\hline $\begin{array}{c}\text { TOTAL } \\
\text { (Number/freq. } \\
(\%))\end{array}$ & $2467 / 43.9$ & $378 / 6.7$ & $30 / 0.5$ & $2002 / 35.6$ & $26 / 0.5$ & $717 / 12.8$ & $5620 / 100.0$ \\
\hline
\end{tabular}

\section{Discussion}

This study set out to describe the epidemiology of penile neoplasm over a long duration of time and it included a large number of cases of penile neoplasms that are not necessarily notified in INCA and DATASUS. However, the analysis was limited by the absence of information concerning a significant number of variables. Nevertheless, this does not debase this evaluation. Health information systems ought to provide reliable data in facilitate an adequate environment for decision making, and efficiently solve public health problems. Such problems found in notification procedures are also common in other countries and might be due to structural regional issues and the availability of adequate equipment, such as personal computers, access to the internet and human resources' capacities (Maia, Assunção, Vidal, \& Vanderlei, 2019).

The main result from this study was a high mortality rate among patients with penile neoplasms and its prevalence in children, adolescents and individuals who are economically active. We hope that this evaluation will prompt legislators to formulate health policies to address this issues and public managers to implement existing policies.

The classic risk factors of penile neoplasms are phimosis and chronic inflammatory diseases, which could be prevented by regular physical examination (Colberg, van der Horst, Jünemann, \& Naumann, 2018). However, information on these risk factors was not available in the databases consulted. The implementation of existing health policies has the potential of preventing penile neoplasms in all ages, but especially among children and young adults (Chipollini, Tang, Sharma, \& Spiess, 2018). 
We illustrated that in more than $80 \%$ of notified cases, the tumor had invaded surrounding tissues. These patients may have postponed seeking for medical assistance due to embarrassment, guilt, fear, denial, many times may have chosen to self-medicate. This late diagnosis decreases the probability of survival and even when the patient survives, there is limited function of the organ and esthetic results from surgical intervention (Ogrich, Stigall, Tyler, \& Hooler, 2018).

In France, penile neoplasms remain a rare condition, but survival rates are conservative, probably due to late diagnosis and limited improvements in self-care (Daubisse-Marliac et al., 2017).

In Brazil, a study done in the state of Maranhão indicated that there was a high frequency of this type cancer among the young, who on average were aged $58.6 \pm 15.7$ years (age range 18 to 103 years), and $20.8 \%$ of them were aged less than 40 years when diagnosed. This represents the world's highest incidence of penile neoplasms, with 6.15 cases per 100 000 habitants. A penectomy was performed in $93.0 \%$ of cases and the vascular invasion of the tumor was present in a statistically significant number of cases in the survival analysis. The study also indicated that low socioeconomical status made it difficult to complete a follow up and the prescribed treatment (Coelho et al., 2018).

A European population-based study indicated that a low level of education, low income, being divorced or single and living alone increased the risk of presenting with an advanced stage of cancer. However, these socioeconomic indicators did not influence the cumulative estimated mortality rate due to specific penile causes. A patient's socioeconomic status influences the stage of his disease but not his prognosis (Torbrand et al., 2017).

The ethnicity of an individual does not seem to be an important predictor for the occurrence of penile neoplasms (Colberg et al, 2018). The low prevalence of cancer among the native population in Brazil maybe be explained by the culture of bathing in the rivers which leads to better penile hygiene, even though they are not generally circumcised (Fonseca, Pinto, Marques, Drosdoski, \& Fonseca Neto, 2010).

Although alcohol consumption is not direct a risk factor for penile neoplasms, individuals with high alcohol consumption are generally diagnosed with a more advanced disease. Those who do not ingest alcohol have a lower risk of the disease (Mclntyre et al., 2011). Our study showed an alcohol consumption rate of 16.0\%; however, this could be $37.0 \%$ if all reported cases in the notification systems were considered. Similarly, the proportion of patients who smoked was $21.0 \%$ and when considering all the reported cases, it surpassed $45.0 \%$. Poor hygiene and alcoholism may explain the occurrence of this disease; unfortunately, this information was not documented for more than $50 \%$ of the cases.

Sociocultural and institutional barriers, poverty and low level of education delay the diagnosis penile cancer and subsequently the commencement of treatment and lead to a poorer prognosis of the disease. In our study, $21.5 \%$ of patients were illiterate, $36.6 \%$ had not finished elementary school and up to $74.5 \%$ of the total had not finished high school. The fear of losing a genital organ and misinformation has been shown to lead to a one-year's delay in diagnosis in up to $50 \%$ of cases (Leone, Diorio, Pettaway, Master, \& Spiess, 2017). Furthermore, being single, living in a rural area, high alcohol consumption and unspecific initial symptoms are significant risk factors for delays in health-seeking which would potentially prevent amputation and sexual impairment due to penile neoplasms. It is not clear why married men had a higher prevalence of penile neoplasms (Torbrand et al., 2017; Gao et al., 2016). Men with this disease usually have a wrong diagnosis, delayed treatment and were reluctant to share this experience with the family, friends and coworkers (Phan et al., 2017).

The glans and the prepuce are the local regions at which the lesions appear in around 70\% of cases (Fonseca et al, 2010). This may be related to a higher prevalence of phimosis in such cases. However, this data was not documented in more than half of analyzed cases. Maia et al. (2019) point out that failing to correctly document information in the notifications systems affects the entire health system's structure, which is essential to generate good indicators for health.

As stated before, the risk factors for penile neoplasms the bad hygiene in the prepuces, infection with HPV, sexual promiscuity, excessive alcohol consumption, smoking, genital infections and both low socioeconomic status and educational level (Mrinakova, Ondrusová \& Ondrus, 2019). Therefore, the men's health risk factors and their life style, the social and community networks at which they live in, their access to the following services: health, education, habitation, sanitation and their environmental, socioeconomical and cultural conditions determine the epidemiology of penile neoplasms (Ribeiro, Aguiar, \& Andrade, 2018).

The incomplete notification of information in the DATASUS system ought to be addressed by public health authorities, given that penile neoplasms affect adolescents and men which are sexual and reproductively active. This cancer, with early diagnosis and treatment, is highly curable and has a low mortality rate. When in an advanced stage, treatment is expensive, and its prognosis is conservative. The amputation of a patient's penis alters his body image and diminishes his his self-esteem making it difficult or even impossible to maintain sexual activity or even the action of urination, and affects him psychologically due to the feeling of a loss of masculinity (Empresa Brasil de Comunicação [EBC], 2013). 


\section{Conclusion}

Penile neoplasms are prevalent in Brazil and the majority of patients are usually diagnosed at an advantage stage of the disease leading to higher mortality rates. Penile neoplasms generally affect the young and economically active population, which is often comprised of Caucasian or Brown, married persons with limited education, living in the Northwest and Southwest regions of the country. A reduction in the prevalence of penile neoplasms might be achieved by promoting men's health and minimizing the risk factors resulting from the cultural and the social determinants of this disease.

\section{References}

Andrade, L., Pelegrini Filho, A., Solar, O., Rigoli, F., Salazar, L., Serrate, P., . . Atun, R. (2014). Social determinants of health, universal health coverage, and sustainable development: case studies from Latin American countries. Lancet, 385(9975), 1343-1351. https://doi.org/10.1016/S0140-6736(14)61494-X

Chipollini, J., Tang, D., Sharma, P., \& Spiess, P. (2018). National Trends and Predictors of Organ-sparing for invasive penile tumors: expanding the therapeutic window. Clin Genitourin Cancer, 383-389. https://doi.org/10.1016/j.clgc.2017.09.004

Coelho, R., Pinho, J., Moreno, J., Garbis, D., Nascimento, A., Larges, J., . . Silva, G. (2018). Penile cancer in Maranhão, Northeast Brazil: the highest incidence globally? BMC Urol, 18(1). https://doi.org/10.1186/s12894-018-0365-0

Colberg, C., van der Horst, C., Jünemann, K., \& Naumann, C. (2018). Epidemiology of penile cancer. Urologe A, 57(4), 408-412. https://doi.org/10.1007/s00120-018-0593-7

Conselho Nacional de Saúde (CNS). (2016). Resolução nº 510/2016. Ética na Pesquisa na área de Ciências Humanas e Sociais: conquista dos pesquisadores. Brazil.

Daubisse-Marliac, L., Colonna, M., Trétarre, B., Defossez, G., Molinié, F., Jéhannin-Ligier, K., . . Grosclaude, P. (2017). Long-term trends in incidence and survival of penile cancer in France. Cancer Epidemiol, 50, 125-131. https://doi.org/10.1016/j.canep.2017.08.014

Ellemers, N. (2018). Gender stereotypes. Anпи Rev Psychol, 69(1), 275-298. https://doi.org/10.1146/annurev-psych-122216-011719

Empresa Brasil de Comunicação (EBC). (2013). Fórum sobre saúde do homem debate exames para detectar câncer de próstata. Brazil.

Ferraz, D., \& Kraiczyk, J. (2010). Gênero e políticas Públicas de Saúde: construindo respostas para o enfrentamento das desigualdades no âbito do SUS. Rev Psicol UNESP, 9(1), 70-82.

Fonseca, A., Pinto, J., Marques, M., Drosdoski, F., \& Fonseca Neto, L. (2010). Estudo epidemiológico do câncer de pênis no Estado do Pará, Brasil. Rev Pan-Amaz Saude, 1(2). https://doi.org/10.5123/S2176-62232010000200010

Freitas, A., \& Coelho, M. (2019). Necessidades humanas de cuidado no homem em tratamento cirúrgico oncológico: implicações para a enfermagem. J Res Fundam Care, 11, 481-487. https://doi.org/10.9789/2175-5361.2019.v11i2.481-487

Gao, W., Song, L., Yang, J., Song, N., Wu, X., Song, N., .. Wang, Z. (2016). Risk factors and negative consequences of patient's delay for penile carcinoma. World J Surg Oncol, 14(1). https://doi.org/10.1186/s12957-016-0863-Z

Leone, A., Diorio, G., Pettaway, C., Master, V., \& Spiess, P. (2017). Contemporary management of patients with penile cancer and lymph node metastasis. Nat Rev Urol, 14(6), 335-347. https://doi.org/10.1038/nrurol.2017.47

Lisbôa, M. (2019). Mortalidade por câncer de pênis: análise de tendência nos estados brasileiros. (Master's thesis, Universidade Federal do Maranhão, São Luiz, Brazil). Fonte: Retrieved from https://tedebc.ufma.br/jspui/handle/tede/2688

Maia, D., Assunção, R., Vidal, A., \& Vanderlei, L. (2019). Avaliação da implantação do Sistema de Informação de Agravos de Notificação em Pernambuco. Epidemiol Serv Saúde, 28(1), 81-87. https://doi.org/10.5123/s1679-49742019000100002

Maroto-Navarro, G., Ocaña-Riola, R., Gil-Garcia, E., \& Garcia-Calvente, M. (2019). Multilevel analysis of global scientific production on parenthood, human development and gender equality. Gac Sanit, 34(6), 582-588. https://doi.org/10.1016/j.gaceta.2019.04.008

Mclntyre, M., Weiss, A., Wahlquist, A., Keane, T., Clarke, H., \& Savage, S. (2011). Penile cancer: an analysis of socioeconomic factors at a southeastern tertiary referral center. Can J Urol, 18(1), 5524-5528.

Ministério da Saúde. Instituto Nacional de Câncer (INCA). (2014). Tipos de câncer: câncer de pênis. Brazil. 
Ministério da Saúde. Secretaria de Atenção À Saúde. Departamento de Ações Programáticas Estratégicas. (2008). Política nacional de atenção integral à saúde do homem. Brazil.

Mrinakova, B., Ondrusová, M., \& Ondrus, D. (2019). Malignant tumors of the penis - Diagnostics and therapy. Klin Oncol, 32(1), 31-39. https://doi.org/10.14735/amko201931

Ogrich, L., Stigall, L., Tyler, W., \& Hooler, W. (2018). Invasive penile squamous cell carcinoma. Cutis, 101(3), 224-227.

Peres, S., Latorre, M., Tanaka, L., Michels, F., Teixeira, M., Coeli , C., \& Almeida, M. (2016). Melhora na qualidade e completude da base de dados do Registro de Cãncer de Base Populacional do município de São Paulo: uso das técnicas de linkage. Rev Bras Epidemiol, 19(4), 753-765. https://doi.org/10.1590/1980-5497201600040006

Phan, M., Deal, A., Ferguson 3rd, J., Wang, Y., Smith, A., Nielsen, M. E., .. . Woods, M. (2017). Contemporary survival trends in penile cancer: Results from the National Cancer Database. Urol Oncol, 35(12), 674.e1-674.e9. https://doi.org/10.1016/j.urolonc.2017.08.009

Ribeiro, K., Aguiar, J., \& Andrade, L. (2018). Determinantes sociais da saúde: o instituído constitucional no sistema Único de Saúde. Rev Bras Promoç Saúde, 31(4), 1-10. https://doi.org/10.5020/18061230.2018.8778

Rice, A., Kim, J., Liu, W., Fall, K., \& Galligan, P. (217). Perceptions of masculinity and fatherhood among men experiencing homelessness. Psychol Serv, 14(2), 257-268. https://doi.org/10.1037/ser0000134

Torbrand, C., Wigertz, A., Drevin, L., Folkvaljon, Y., Lambe, M., Hakansson, U., \& Kirrander, P. (2017). Socioeconomic factors and penile cancer risk and mortality; a population-based study. BJU, 119(2), 254-260. https://doi.org/10.1111/bju.13534

\section{Copyrights}

Copyright for this article is retained by the author(s), with first publication rights granted to the journal.

This is an open-access article distributed under the terms and conditions of the Creative Commons Attribution license which permits unrestricted use, distribution, and reproduction in any medium, provided the original work is properly cited. 